\title{
A dual-target strategy for the detection of Chlamydia trachomatis by real-time PCR
}

\author{
Y. A. Vitrenko, O. M. Deryabin \\ State Scientific Control Institute of Biotechnology and Strains of Microorganisms \\ 30 Donetska Str., Kyiv, Ukraine, 03151 \\ yavit@yahoo.com,admin@biocontrol.com.ua
}

\begin{abstract}
The first-generation tests targeting a cryptic plasmid for the C. trachomatis diagnostics showed a relatively high sensitivity; however their usefulness has recently been compromised by the discovery of C. trachomatis strains lacking the target DNA segment (e.g. the "Swedish" variant) or variants bearing no plasmid at all and thus escaping the diagnostics. Aim. We propose the addition of a $C$. trachomatis chromosome gene as a PCR target to back up plasmidbased assays and enhance the overall efficiency of diagnostics. Methods. Two multiplexed PCRs were set up to target $C$. trachomatis cryptic plasmid and the $16 \mathrm{~s}$ rRNA gene. The $16 \mathrm{~s}$ rRNA primers produce PCR signal from a range of Chlamydia species whereas the introduction of a Taqman probe (essential for the real-time PCR) scales the assay down to C. trachomatis. At the same time, our plasmid PCR is specific to $C$. trachomatis exclusively. Results. The sensitivity of plasmid and 16s rRNA PCRs ranged between one to ten genome-equivalents per reaction (geq/rxn) whereas the efficiency was always $\sim 100 \%$. Multiplexing did not reduce the analytical sensitivity. Addition of DNA prepared from clinical specimens to the reaction mix did not affect PCR with pure $C$. trachomatis DNA further demonstrating the robustness of this system. The kinetics of the two reactions was compared in 49 DNA samples prepared from C. trachomatis-positive swabs. In 45, reactions showed a good correlation in the threshold cycle of amplification $C q$, the main analytical parameter of real-time PCR. Conclusions. The simultaneous detection of chromosomal and plasmid targets in the multiplex PCR offers a high sensitivity and is particularly advantageous for specimens where the plasmid might be lost due to DNA degradation or counter-selection after treatment. The dual PCR strategy constitute the core of a diagnostic test for both in-house and commercial use.
\end{abstract}

Ke y w or d s: Chlamydia trachomatis, real-time PCR, 16s rRNA, cryptic plasmid

\section{Introduction}

Chlamydia is a causative agent of a series of urogenital, respiratory and ocular disor- ders in humans and animals [1]. Although in most cases infections are asymptomatic, severe outcomes occur when the pathogenassociated damage is aggravated by an in-

(C) 2018 Y. A. Vitrenko et al.; Published by the Institute of Molecular Biology and Genetics, NAS of Ukraine on behalf of Biopolymers and Cell. This is an Open Access article distributed under the terms of the Creative Commons Attribution License (http://creativecommons.org/licenses/by/4.0/), which permits unrestricted reuse, distribution, and reproduction in any medium, provided the original work is properly cited 
adequate immune response $[2,3]$. C. trachomatis is the most clinically important and hence best-studied representative of the phylum. This is a sexually transmitted obligate intracellular gram-negative bacterium. If not treated it can cause pelvic inflammatory disease, infertility, ectopic pregnancy, urethritis, infant pneumonia and blindness [3]. Therapy of C.trachomatis infection relies mainly on broad-spectrum antibiotics such as azithromycin and doxycycline, and no pathogen-specific treatment has been implemented as yet [4].

The diagnostics of Chlamydia infection in humans and animals makes a wide use of PCR [4]. For C. trachomatis, the cryptic plasmid which is somehow linked with infectivity [5] has long been the primary target in PCR tests [6]. The plasmid is present in up to 10 copies per cell [7]. However, a variant was discovered in Sweden where the plasmid had a deletion encompassing the target region used in diagnostic kits of that time $[8,9]$. It was suggested that the deletion had been rapidly selected due to the diagnostic advantage it provided to the microorganism oppressed by screening programs. Moreover, plasmid-less variants have also been reported $[10,11]$. Therefore, other PCR targets have been suggested: momp1 (major outer membrane protein) [12], omcB (outer membrane complex B protein) [13], gyrase A [14], 16s rRNA [10, 15], 23s rRNA

Here we present a set of PCRs targeting the C. trachomatis cryptic plasmid, 16s rRNA gene and a synthetic plasmid as an internal control. These reactions could constitute the basis of an in-house or affordable commercial diagnostic kit. They are highly sensitive, robust and amenable for multiplexing. The dual-target strategy appears to be particularly useful for problematic specimens in which a partial loss of DNA due to degradation or deletion might be an issue.

\section{Methods}

\section{Samples}

Chlamydia reference DNA samples were obtained as a gift from the German Reference Center for Chlamydial Infections at the Institute of Microbiology, Friedrich-Schiller-University Jena (Jena, Germany); Bacillus cereus DNA was a gift from Dr. Tigran Yuzbashev (Institute for Genetics and Selection of Industrial Microorganisms, Moscow, Russia). Lactobacillus rhamnosus DNA was isolated from a culture purchased at Probiotical SpA (Novara, Italy). Escherichia coli, Bacillus cereus, Listeria monocytogenes, Mycoplasma arginini, Campylobacter pylori DNA was isolated from stocks deposited at the State Scientific Control Institute of Biotechnology and Strains of Microorganisms (Kyiv, Ukraine). DNA isolation was done using GeneJET Genomic DNA Purification Kit (Thermo Fisher Scientific, Waltham, MA, USA). Clinical specimens (vaginal, endocervical and urethral swabs) were kindly provided by several commercial and hospital labs in Kyiv, Ukraine. Patients ordering a $C$. trachomatis PCR test have signed consent for research use of their specimens. The Ethic Committee of the State Scientific Control Institute of Biotechnology and Strains of Microorganisms approved the use of human clinical specimens in this research. All biological materials were properly destroyed. 


\section{Internal control}

A pUC18 - based plasmid bearing Thermus thermophilus tRNA ${ }^{\mathrm{Tyr}}$ gene as a SmaI - BamHI insert was kindly provided by Prof. Mykhailo Tukalo (Institute of Molecular Biology and Genetics, Kyiv, Ukraine).

\section{$P C R$}

PCR was performed with oligonucleotides (Table 1) designed with the aid of the Vector NTI ${ }^{\circledR}$ software (Thermo Fisher Scientific, Waltham, MA, USA) and primer-BLAST (https://www.ncbi.nlm.nih.gov/tools/primerblast). The reaction volume was $25 \mu 1$. The oligonucleotide quantity per reaction was as given in Table (right column). Other components were: 1x DreamTaq PCR buffer, $0.1 \mathrm{mM}$ dNTP, $3 \mathrm{mM}$ $\mathrm{MgCl}_{2}, 0.6 \mathrm{mg} / \mathrm{ml}$ bovine serum albumin, $4 \%$ glycerol, DreamTaq polymerase (Thermo Fisher Scientific, Waltham, MA, USA) or TaqF polymerase (Interlabservice, Moscow, Russia). PCR program was: pre-denaturation, $95{ }^{\circ} \mathrm{C}$ for 10 min; amplification for $40-45$ cycles of: $95^{\circ} \mathrm{C}$ for $10 \mathrm{sec}, 62{ }^{\circ} \mathrm{C}$ for $20 \mathrm{sec}, 72^{\circ} \mathrm{C}$ for $30 \mathrm{sec}$. Typically, 5 ul sample DNA were added to PCR. Real-time PCR was done on a Biorad CFX-96 PCR system (Biorad, Hercules, CA, USA).

The threshold cycle of amplification $C q$ was registered as a point at which the amplification curve reached the intensity of fluorescence of 50 relative units. The efficiency of PCR was calculated using the formula:

$$
E=10^{-1 / \text { slope }}-1
$$

where $E$ - efficiency, "slope" - the slope of the trend line of the $C q$ dependence on the $\log _{10}$ of concentration of reference C. trachomatis DNA (Fig. $3 B$ and $C$ ).

\section{Results}

\section{Primers, probes and target regions}

Our principle idea was to supplement a plasmidbased reaction with another one targeting some genomic fragment. Thus the test would be insured from plasmid-instability issues while keeping an elevated level of the analytical sensitivity suggestively provided by several copies of plasmid. The 16s rRNA gene was chosen as the target genomic fragment due to a unique pattern of conservative and hypervariable motives [15]. There are two copies of this gene in C. trachomatis separated by about $20 \mathrm{~kb}$ (Fig. 1A). Primers were designed to detect a range of Chlamydia species thus reserving a possibility of detecting the Chlamydia genus without specification which might be in demand in certain clinical and veterinary situations. At the same time, the hexachlorofluorescein (HEX)-labeled Taqman probe is C. trachomatis - specific: mismatches to the corresponding sequence of other species are sufficient to abrogate the detection in real-time PCR (Fig. 1A).

The cryptic plasmid is detected by a pair of primers targeting the predicted coding sequence CDS3 (Fig. 1B). Note that the targeted region lies outside of the 377-bp Swedish deletion. The function of CDS3 is yet unknown; interaction with other plasmid-born CDSs and chromosomal genes has been suggested [16]. The probe is labeled by 6-carboxyfluorescein (FAM) thus enabling multiplexing with the $16 \mathrm{~s}$ rRNA PCR detected by HEX fluorescence.

If PCR reaction is aimed to be used as a diagnostic test it must be accompanied by an internal control reaction. A positive PCR signal from the internal control would indicate that PCR conditions were correct and the compo- 
A

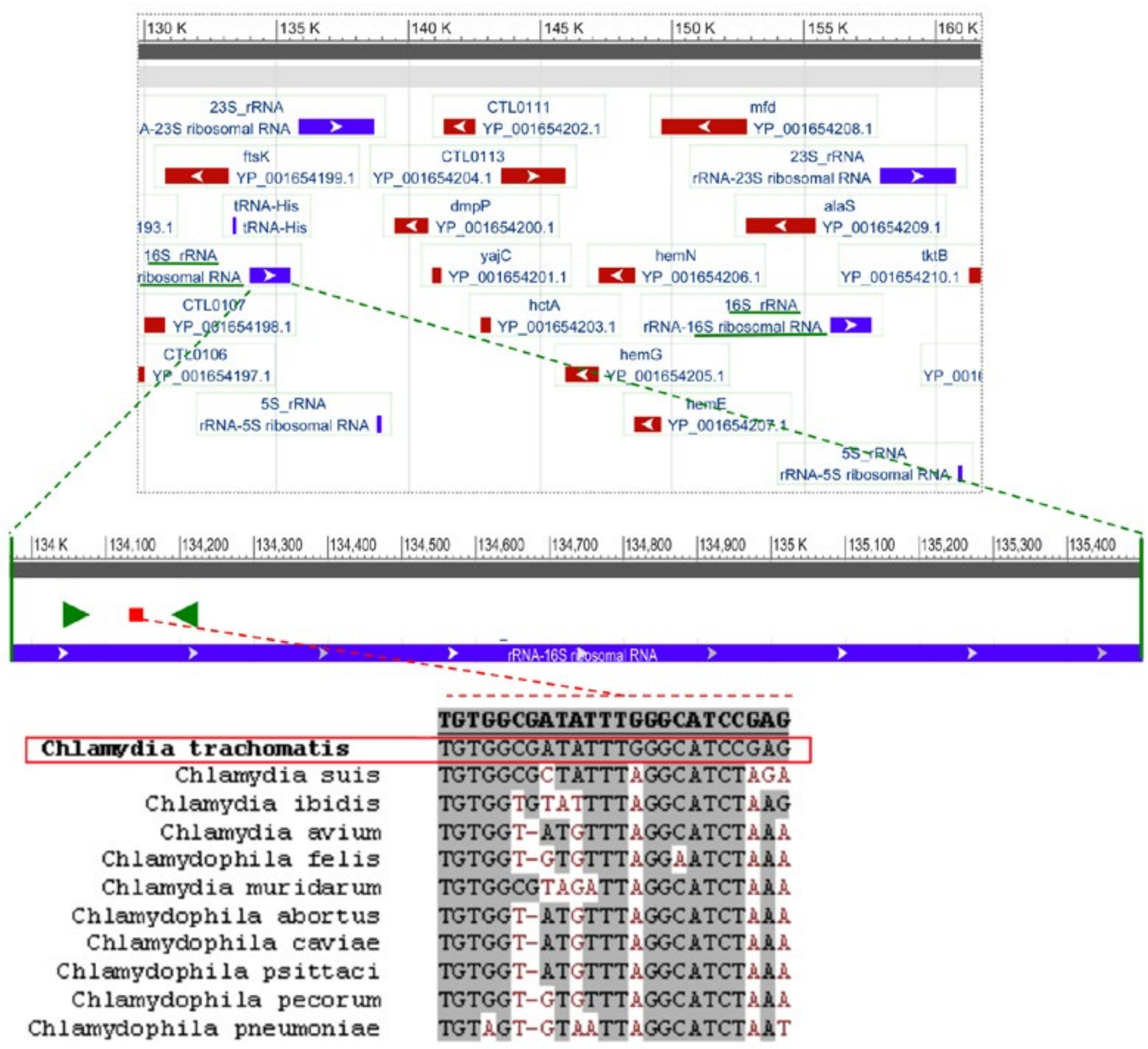

B

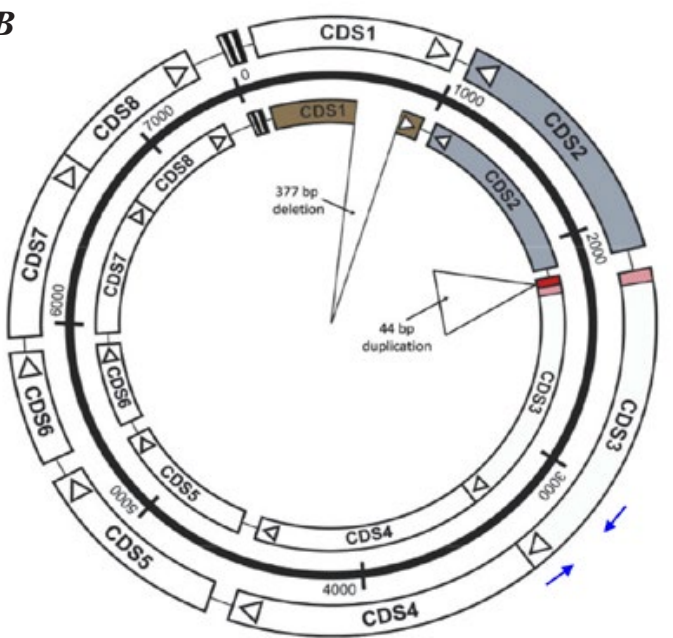

Fig. 1. PCR targets for C. trachomatis detection. $A$ - The 16s rRNA gene on $C$. trachomatis $434 / \mathrm{Bu}$ chromosome (GeneBank NC 010287.1). One of the two 16s rRNA loci is zoomed to show the region targeted by primers (green arrowheads) and probe (red block). Rulers above the maps show the chromosomal coordinate in kilobase pairs. The probe sequence is given in bold. The corresponding sequences of Chlamydia species are shown with mismatches highlighted by red letters. $B-C$. trachomatis cryptic plasmids. Plasmid with rearrangements characteristic of the Swedish variant is shown by the inner circle, wild-type by the outer. Positions of primers are shown by arrows. This panel is adopted from a diagram published earlier [9]. A kind permission of the author, Dr. Helena Seth-Smith, was granted. 
nents of the PCR machinery worked properly. In this case, a negative result of the target reaction could surely be interpreted as the absence of the pathogen DNA in the sample (or its presence below the sensitivity threshold), not as a result of PCR failure. We designed a third reaction templated by the $p U C 18$ plasmid bearing an insert in the multiple cloning site (see Materials and Methods). This plasmid should be added to the reaction mix along with sample DNA. The forward primer anneals to the insert; the reverse primer anneals to the bLactamase gene which is a part of the original pUC18 backbone sequence. It was crucial to position one of the primers to a synthetically introduced insert. If we otherwise placed both primers to the backbone an undesirable background PCR signal would be produced from the homologous expression vectors usually present in recombinant Taq polymerase stocks as an admixture. Note that such vectors are inevitably carried over to the PCR mix and produce a detectable amplicon [17] after about 30 cycles (data not shown). The Taqman probe for this reaction carries the cyanine 5 (Cy5) dye whose maximum of fluorescence emission $(670 \mathrm{~nm})$ lies away from that of FAM $(517 \mathrm{~nm})$ and $\operatorname{HEX}(556 \mathrm{~nm})$ labeling the 16s rRNA and cryptic plasmid reactions, respectively. PCR with 16s rRNA primers amplified a distinct 156-bp product from purified DNA of C. trachomatis (Fig. 2, lanes 2 and 3) and some other Chlamydia species (Fig. 2, lanes 8-14). No 156-bp product was detected in DNA from Escherichia coli, Bacillus cereus, Listeria monocytogenes, Mycoplasma arginini (Fig. 2, lanes 4-7), Bacillus thermocatenulatus, Campylobacter pylori, Lactobacillus rhamnosus (data not shown). Non-specific products of a higher molecular weight seen in PCR from some non-Chlamydia species have no diagnostic value. Cryptic plasmid, appearing as a 266-bp product, was detected only in PCR from C. trachomatis DNA (Fig. 2, lane 3).

\section{PCR from reference C. trachomatis DNA}

A triplex PCR consisting of reactions targeting the 16s rRNA gene and cryptic plasmid of reference $C$. trachomatis along with internal control produced a typical sigmoid curve (Fig. 3A) and distinct electrophoretic band (Fig. $3 B$ ) for each of the three reactions. Note that the internal control PCR (smooth grey curves) does not appear to be inhibited by the two diagnostic reactions (symbol-marked curves) even at elevated concentrations of template DNA. The individual analytical sensitivity of the diagnostic reactions in triplex was assayed on ten-fold dilutions of pure C. trachomatis DNA spanning four orders of magnitude (Fig. $3 C$ and $D$ ). Reproducible sigmoid curves were observed for both reactions in the presence of as low as five genome-equivalents per

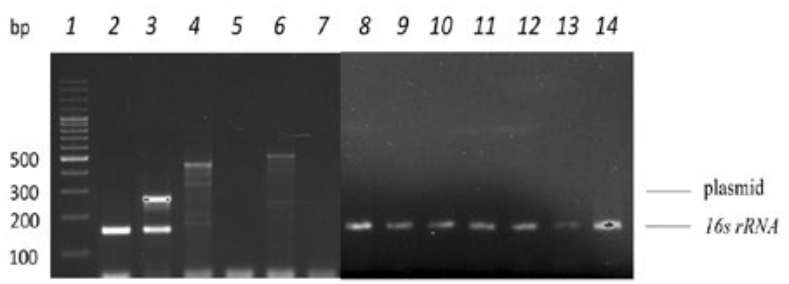

Fig. 2. PCR from the 16s rRNA gene and cryptic plasmid on reference strains. Amplicons generated with primers to 16s rRNA (2-14) and plasmid (3-14). 1 - Molecular weight marker producing the bands whose sizes are shown in base pairs (bp). 2,3 - Chlamydia trachomatis, 4-Escherichia coli, 5 - Bacillus cereus, 6 - Listeria monocytogenes, 7 - Mycoplasma arginini, 8 - Chlamydia suis, $9-$ C. mudidatum, $10-$ C. abortus, $11-$ C. felis, $12-$ C. psittaci, $13-$ C. avium, $14-C$. pecorum 
$\boldsymbol{A}$

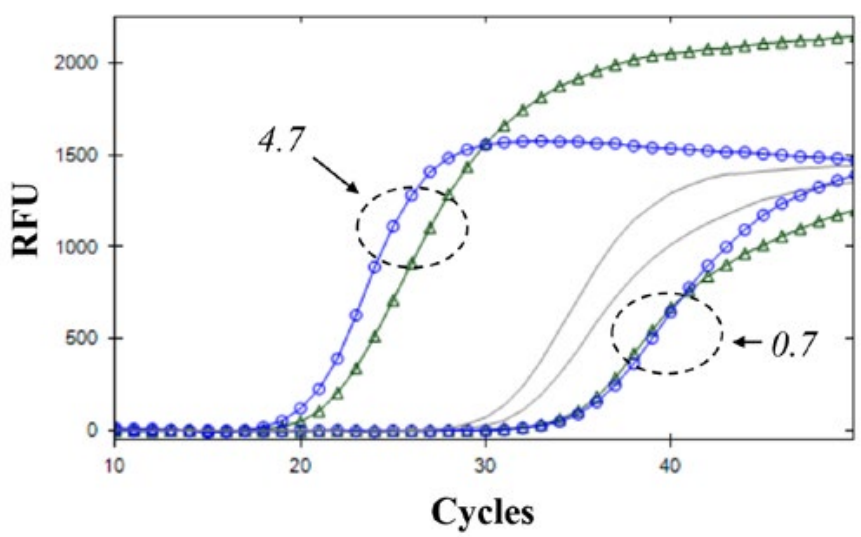

C

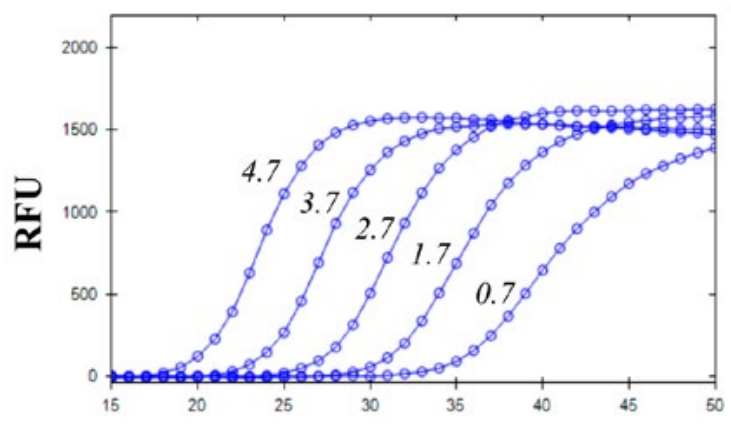

Cycles

D

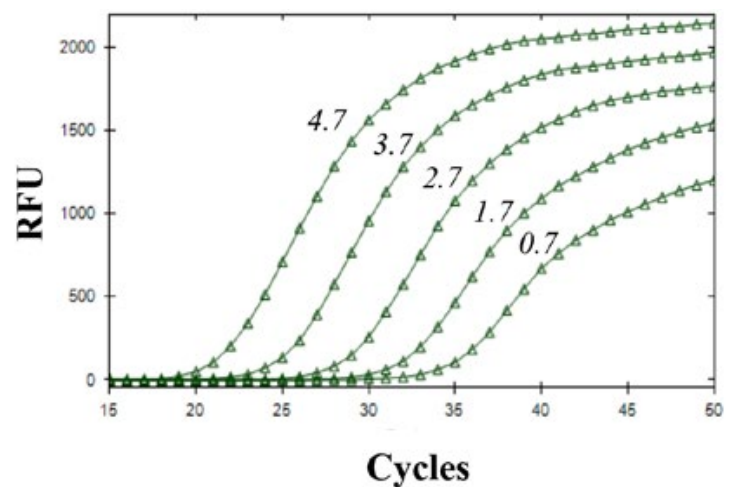

$\boldsymbol{B}$
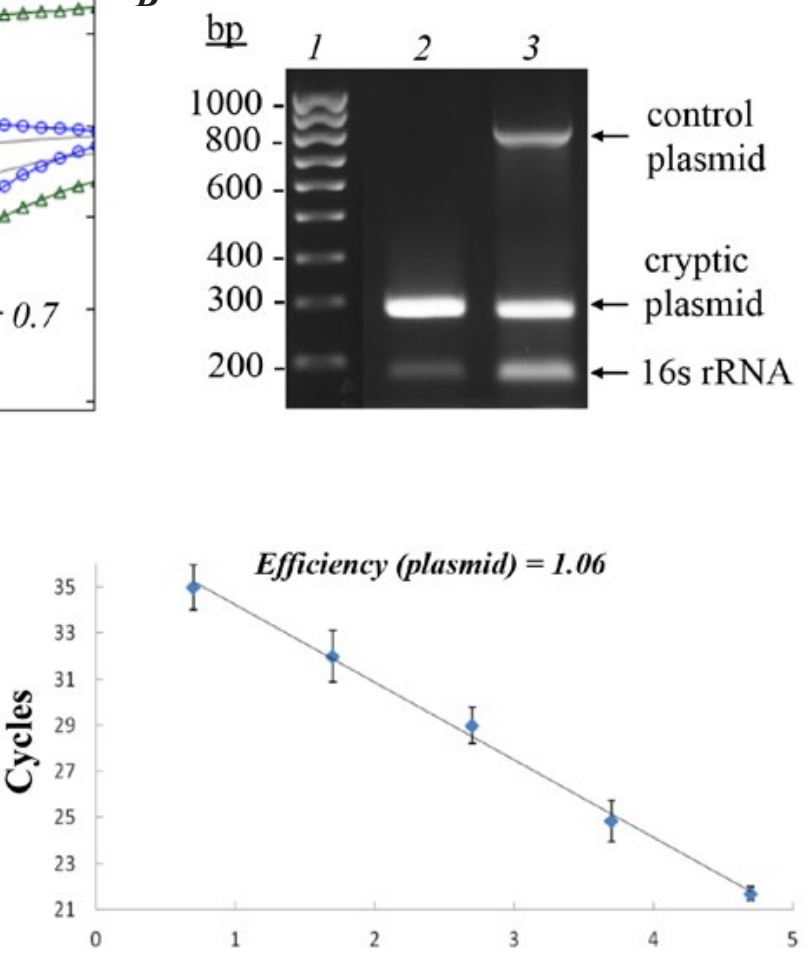

Log concentration

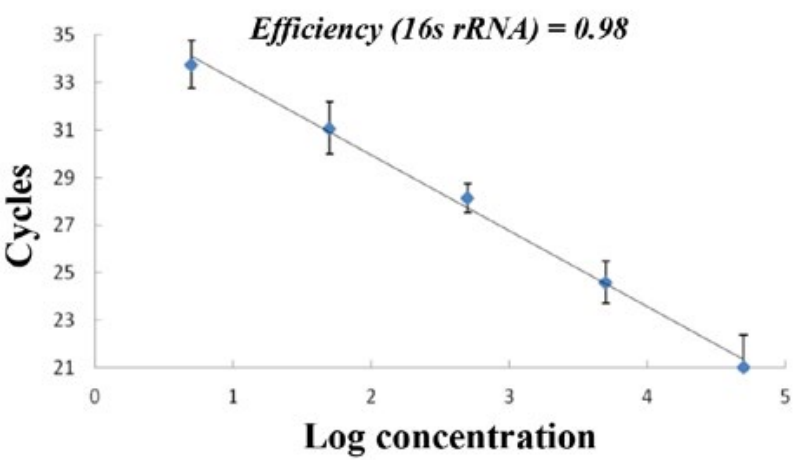

Fig. 3. Sensitivity and efficiency of multiplex PCR for C. trachomatis. A - Triplex real-time PCR with primers to 16s rRNA (green triangles), cryptic plasmid (blue circles) and internal control (grey). C. trachomatis DNA was added in the amount indicated as $\log _{10} \mathrm{geq} / \mathrm{rxn}$. The internal control was added as well. B - PCR from C.trachomatis DNA without (lane 2) or with (lane 3) the addition of internal control plasmid. Molecular weight marker (lane 1) produces bands whose sizes are shown in base pairs (bp). $C$ - Of three reactions, only the one targeting cryptic plasmid is shown. The PCR efficiency was deduced from the plot of $C q$ to $\log$ geq/rxn given at the right (mean of three reactions, error bar: standard deviation). $D$ - same as (c) but for 16s rRNA PCR. 
reaction mix (which is equal to the value of 0.7 in the logarithmic form). We monitored $C q$, a PCR cycle at which the kinetics passes from the lag to exponential stage. The $C q$ is considered as the main quantitative parameter of realtime PCR. In our assays, a ten-fold increment in the template concentration translated in the $C q$ decrease of about 3.3 cycles throughout the entire concentration range. Consequently, the PCR efficiency was close to one (100\%) indicating that (i) no loss of sensitivity happens upon dilution of the sample, (ii) no inhibition is caused by higher concentrations of template DNA.

It is often speculated that multiplexing might weaken PCR because of unpredictable oligonucleotide heteroduplexes and/or exhausting PCR components. We compared the performance of our diagnostic reactions in the monoplex versus triplex format (Fig. 4, smooth and symbol-marked curves, respectively).

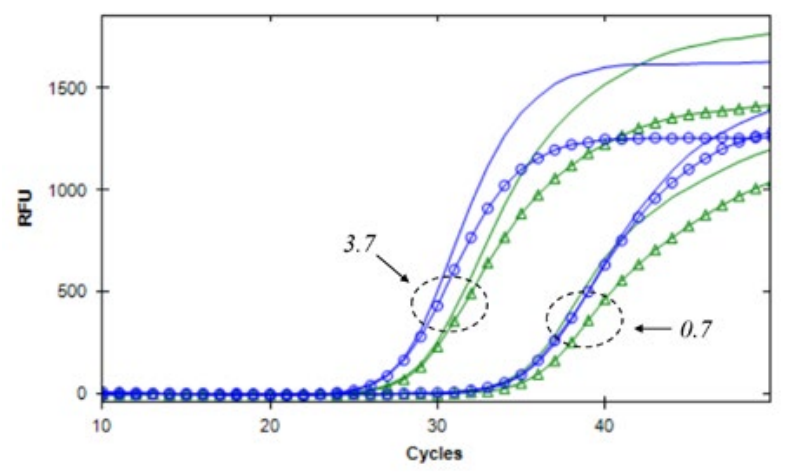

Fig. 4. A negligible effect of multiplexing on the PCRs for $C$. trachomatis. Pure C. trachomatis DNA was used to give the indicated number of $\log _{10}$ geq/rxn. PCR was done either in triplex with primers to 16s rRNA (green triangles) + cryptic plasmid (blue circles) + internal control (not shown) or monoplex with primers to 16s rRNA or cryptic plasmid (green and blue curves, respectively, without any symbol).
No significant change in $C q$ and overall shape of curves has been observed at both high (4.7 $\log _{10}$ geq/rxn) and low $\left(0.7 \log _{10}\right.$ geq/rxn) concentrations of pure C. trachomatis DNA. Thus we could dispel concern of a sensitivity loss due to multiplexing.

\section{Clinical samples}

Up to this point, the proposed strategy of dualtarget PCR has been tested only on pure reference DNA. Skepticism might hold that DNA from real clinical specimens could perform weaker in terms of the sensitivity and robustness. In view of this, we examined our reactions in triplex on reference $C$. trachomatis DNA with and without DNA isolated from C. trachomatis-negative specimens (Fig. 5, symbol-marked and smooth curve, respectively). Plasmid and 16s rRNA PCRs (Fig. $5 \mathrm{~A}$ and $B$, respectively) produced a detectable fluorescent signal throughout a range of template DNA concentrations spanning four orders of magnitude. We did not observe any significant difference between real-time PCR curves registered in the presence or absence of clinical sample DNA. Thus the proposed PCR reactions are robust enough for the detection of C. trachomatis DNA in clinical specimens.

Next we compared the performance of $16 \mathrm{~s}$ rRNA and cryptic plasmid reactions on real C. trachomatis - positive samples (deemed such by commercial PCR kits; Fig. 6). We carried out triplex PCR (with the addition of internal control) and plotted the results as dots on the plane formed by two $C q$ values. In such representation, the results lie along the diagonal line indicating that the two reactions sense the variation of the amount of $C$. trachomatis DNA in a similar manner. There were 45 such 

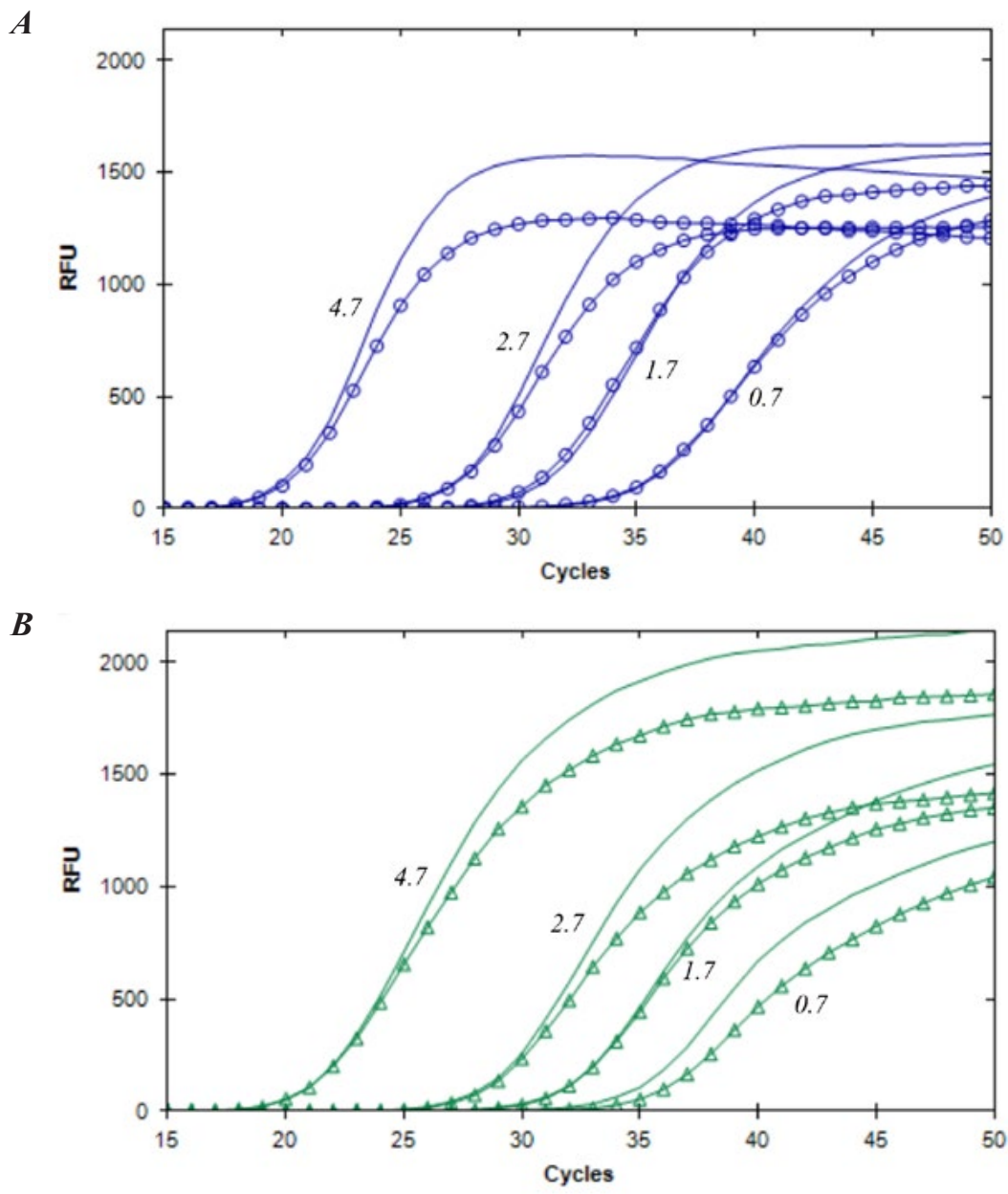

Fig. 5. A negligible effect of DNA prepared from a clinical specimen on the PCRs for C. trachomatis. Pure C. trachomatis DNA was used to give the indicated number of $\log _{10}$ geq/rxn. PCR was done in triplex with primers to $16 \mathrm{~s}$ rRNA + cryptic plasmid + internal control. Of the three reactions, only cryptic plasmid $(A)$ or $16 \mathrm{~s}$ rRNA $(B)$ PCRs are shown. Curves registered in the presence of DNA from a C. trachomatis - negative clinical sample are labelled with triangles or circles.

samples out of total 49 . In four outliers, one of the two reactions failed or poorly performed as judged by a higher $C q$ : one with plasmid and three with $16 \mathrm{~s}$ rRNA. These results were essentially confirmed by re-analyzing the backup stocks starting from DNA (data not shown). Overall, the two reactions were equally efficient on clinical specimens: the mean $C q$ was 28.2 and 28.3 for cryptic plasmid and $16 \mathrm{~s}$ rRNA, respectively. Therefore, 16s rRNA and cryptic plasmid PCRs can complement each other in problematic cases thereby minimizing the chance of a false-negative result.

\section{Discussion}

About 90 million cases of $C$. trachomatis infection are diagnosed worldwide and the incidence has grown within the last decade [18]. A large proportion of infections proceeds asympthomatic and undetected, yet pelvic inflammatory disease could develop with a various probability and cause infertility in up to $18 \%$ of cases [19]. Despite screening programs have been designed and promoted recently [20], many communities and regions still have a limited access to high-quality $C$. trachomatis diagnostics. The advent of molecular techniques, such 


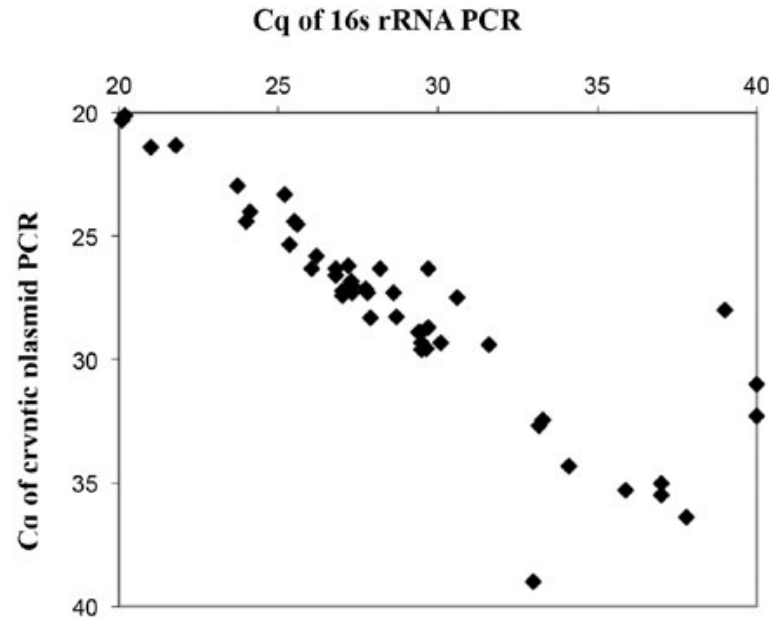

Fig. 6. Scatter of $C q$ values of PCR from clinical samples. Forty nine clinical C. trachomatis - positive samples were assayed by 16s rRNA and plasmid PCR and plotted on the plane of the corresponding $C q$ values.

as PCR, holds a great promise to improve the management of infectious diseases at the population level in general.

Here we suggested that targeting two loci could greatly improve $C$. trachomatis PCR diagnostics. We chose the 16s rRNA gene as the chromosomal target to supplement plasmid-born PCR. First, it is present in at least two copies (Fig. 1A) thus backing up the test if one of the copies picks up a mutation affecting the primer - template interaction. Second, we wanted to reserve an option to detect nontrachomatis Chlamydiaceae which would expand the use of 16s rRNA reaction in clinical and veterinary diagnostics. The 16s RNA gene offers enough conserved motives for designing primers to $16 \mathrm{~s}$ rRNA sequence from a range of Chlamydia species (Fig. 2). At the same time, our Taqman probe (Fig. 1A) was sufficiently restrictive narrowing down the range to $C$. trachomatis (Fig. 3 and data not shown).
The sensitivity and efficiency were similar for 16s rRNA and plasmid PCR, on both pure DNA (Fig. 3) and clinical samples (Fig. 6). The reactions were performed well in the multiplex format (Figs. 3 and 4). Thus the system does not appear to be affected by a reciprocal inhibiting effect of the reactions and exhaust of active components towards the end of PCR. Furthermore, the reactions were not perturbed by inhibitors potentially carried through the DNA isolation step (Fig. 5 and data not shown). Thus this PCR set could be combined with various DNA isolation kits and integrated into an existing laboratory workflow. Despite a high analytical sensitivity, the clinical sensitivity of a test based on the proposed reactions remains to be determined. This should be done on a panel of reference clinical samples prepared under the same conditions and deemed C. trachomatis-positive by a "golden standard" test.

For the quantification of C. trachomatis, $16 \mathrm{~s}$ rRNA PCR appears more advantageous because the plasmid copy number is a variable parameter per se. Our results show that $16 \mathrm{~s}$ rRNA, as a PCR target, is not worse than plasmid used traditionally. However, it would be premature to refuse from targeting the plasmid which is believed to be somehow associated with virulence [5]. It is plausible that the diagnostics of the future will be focused more on highly virulent stages and variants in order to avoid unnecessary therapeutic measures.

In rare samples, one of the two reactions failed (Fig. 6) which could be caused by (i) partial DNA degradation, (ii) sequence variation in primer target sites, (iii) infection eradication. In general, since many aspects of C. trachomatis biology and pathogenesis still 
Table. Oligonucleotides used in this study

\begin{tabular}{|l|c|c|l|c|c|}
\hline \multicolumn{1}{|c|}{ Name } & Target & 5' - mod & \multicolumn{1}{|c|}{ Sequence } & 3' - mod & $\begin{array}{c}\text { Quantity, } \\
\text { pmol/rxn }\end{array}$ \\
\hline CT 16s OD fwd & & & AGTGGCGGAAGGGTTAGTAATG & & 10 \\
CT 16s OD rev & 16s rRNA & & TCACATAGACTCTCCCTTAACCGA & & 10 \\
CT 16s OD probe & & HEX & TGTGGCGATATTTGGGCATCCGAG & BHQ2 & 3 \\
CT CP OD fwd & & & GCGAATCAGATCCGGTTGC & & 15 \\
CT CP OD rev & Cryptic & & CACATCTGCCGTCTTGCTCTATTTG & & 15 \\
CT CP OD probe & \multirow{2}{*}{ FAM } & TGCTTTCAGATTTGCGAGACAGCGGT & BHQ1 & 3 \\
bLctm fwd & & & TTTCCGTGTCGCCCTTATTC & & 5 \\
bLctm rev & pUC18 & & CCCAACTGATCTTCAGCATCTT & & 5 \\
bLctm probe & plasmid & \multirow{2}{*}{ Cy5 } & TGCTCACCCAGAAACGCTGG & BHQ3 & 2 \\
\hline
\end{tabular}

remain unclear we suggest that a PCR diagnostic kit must be somewhat redundant. The use of two reactions, able to back-up each other on problematic samples, appears to be advantageous for the test's reliability.

\section{Conclusions}

The dual-target strategy for PCR detection of C. trachomatis presented here benefits from the simultaneous targeting the cryptic plasmid and 16s rRNA gene. Such a strategy offers a high sensitivity and reproducibility, performs well upon multiplexing, and ensures an efficient $C$. trachomatis detection in samples where one of the targets is lost. Adoption of these reactions could be a launching point in the development of a quantitative kit for both in-house use and commercial production.

\section{List of abbreviations}

PCR, polymerase chain reaction; $C q$ - threshold cycle in PCR amplification; geq/rxn, genome-equivalents per reaction; bp, base pairs. FAM,6-carboxyfluorescein; HEX, hexachlorofluorescein; Cy5, cyanine-5; BHQ-1,2 and 3 , black-hole quencher-1,2 and 3, respectively.

\section{Funding}

This research was performed in the framework of the "Program for Typing and Certification of Microbial and Virial Stocks in Profile Institutions" curated by the State Scientific Control Institute of Biotechnology and Strains of Microorganisms. Y.V. was supported by Ukrmedspilka, Ltd, Kyiv, Ukraine

\section{Acknowledgements}

We are grateful to Dr. Maria Obolenska (Institute of Molecular Biology and Genetics, Kyiv, Ukraine) for providing her lab premises for some experiments. We also thank Mykhailo Tukalo (Institute of Molecular Biology and Genetics, Kyiv, Ukraine) for the $p U C 18-t R N A^{\mathrm{Tyr}}$ plasmid.

\section{REFERENCES}

1. Hooppaw AJ, Fisher DJ. A Coming of Age Story: Chlamydia in the Post-Genetic Era. Infect Immun. 2015;84(3):612-21.

2. Beatty WL, Morrison RP, Byrne GI. Persistent chlamydiae: from cell culture to a paradigm for chlamydial pathogenesis. Microbiol Rev. 1994;58(4):686-99.

3. Elwell C, Mirrashidi K, Engel J. Chlamydia cell biology and pathogenesis. Nat Rev Microbiol. 2016;14(6):385-400. 
4. Lanjouw E, Ouburg S, de Vries HJ, Stary A, Radcliffe K, Unemo M. 2015 European guideline on the management of Chlamydia trachomatis infections. Int J STD AIDS. 2016;27(5):333-48.

5. Carlson JH, Whitmire WM, Crane DD, Wicke L, Virtaneva K, Sturdevant DE, Kupko JJ 3rd, Porcella SF, Martinez-Orengo N, Heinzen RA, Kari L, Caldwell $H D$. The Chlamydia trachomatis plasmid is a transcriptional regulator of chromosomal genes and a virulence factor. Infect Immun. 2008;76(6):2273-83.

6. Ostergaard L, Birkelund S, Christiansen G. Use of polymerase chain reaction for detection of Chlamydia trachomatis. J Clin Microbiol. 1990;28(6):1254-60.

7. Palmer L, Falkow S. A common plasmid of Chlamydia trachomatis. Plasmid. 1986;16(1):52-62.

8. Unemo M, Clarke IN. The Swedish new variant of Chlamydia trachomatis. Curr Opin Infect Dis. 2011;24(1):62-9.

9. Seth-Smith HM, Harris SR, Persson K, Marsh P, Barron A, Bignell A, Bjartling C, Clark L, Cutcliffe LT, Lambden PR, Lennard $N$, Lockey SJ, Quail MA, Salim O, Skilton RJ, Wang Y, Holland MJ, Parkhill J, Thomson NR, Clarke IN. Co-evolution of genomes and plasmids within Chlamydia trachomatis and the emergence in Sweden of a new variant strain. BMC Genomics. 2009;10:239.

10. An $Q$, Olive DM. Molecular cloning and nucleic acid sequencing of Chlamydia trachomatis $16 \mathrm{~S}$ rRNA genes from patient samples lacking the cryptic plasmid. Mol Cell Probes. 1994;8(5):429-35.

11. Yeow TC, Wong WF, Sabet NS, Sulaiman S, Shahhosseini F, Tan GM, Movahed E, Looi CY, Shankar EM, Gupta R, Arulanandam BP, Hassan J, Abu Bakar $S$. Prevalence of plasmid-bearing and plasmid-free Chlamydia trachomatis infection among women who visited obstetrics and gynecology clinics in Malaysia. BMC Microbiol. 2016;16:45.

12. Dutilh B, Bébéar C, Rodriguez P, Vekris A, Bonnet J, Garret $M$. Specific amplification of a DNA sequence common to all Chlamydia trachomatis serovars using the polymerase chain reaction. Res Microbiol. 1989;140(1):7-16.

13. Pickett MA, Everson JS, Pead PJ, Clarke IN. The plasmids of Chlamydia trachomatis and Chlamydophila pneumoniae (N16): accurate determination of copy number and the paradoxical effect of plasmid-curing agents. Microbiology. 2005;151(Pt 3):893-903.

14. Patel AL, Sachdev D, Nagpal P, Chaudhry U, Sonkar SC, Mendiratta SL, Saluja D. Prevalence of Chlamydia infection among women visiting a gynaecology outpatient department: evaluation of an in-house PCR assay for detection of Chlamydia trachomatis. Ann Clin Microbiol Antimicrob. 2010;9:24. doi: 10.1186/1476-0711-9-24.

15. Monstein HJ, Kihlström E, Tiveljung A. Detection and identification of bacteria using in-house broad range 16S rDNA PCR amplification and genusspecific DNA hybridization probes, located within variable regions of $16 \mathrm{~S}$ rRNA genes. APMIS. 1996;104(6):451-8.

16. Gong S, Yang Z, Lei L, Shen L, Zhong G. Characterization of Chlamydia trachomatis plasmid-encoded open reading frames. $J$ Bacteriol. 2013;195(17):3819-26.

17. Chiang CS, Liu CP, Weng LC, Wang NY, Liaw GJ. Presence of beta-lactamase gene TEM-1 DNA sequence in commercial Taq DNA polymerase. J Clin Microbiol. 2005;43(1):530-1.

18. Mylonas I. Female genital Chlamydia trachomatis infection: where are we heading? Arch Gynecol Obstet. 2012;285(5):1271-85.

19. Haggerty CL, Gottlieb SL, Taylor BD, Low N, Xu F, Ness $R B$. Risk of sequelae after Chlamydia trachomatis genital infection in women. $J$ Infect Dis. 2010;201 Suppl 2:S134-55.

20. Phillipson L, Gordon R, Telenta J, Magee C, Janssen $M$. A review of current practices to increase Chlamydia screening in the community - a consumer-centred social marketing perspective. Health Expect. 2016;19(1):5-25.

\section{Двоцільова стратегія виявлення Chlamydia trachomatis за допомогою ПЛР у реальному часі}

\section{Я. О. Вітренко, О. М. Дерябін}

Мішенню тестів діагностики C. trachomatis першого покоління є криптична плзмда. Нещодавно відкриті штами без цільового сегмента ДНК (т.зв. «Шведскі» варіанти) або повністю позбавлені плазміди не діагностуються ПЛР. Мета. Запропоновано використовувати хромосомний ген в якості додаткової мішені, що дозволить підстрвахувати плазмідний ПЛР-тест і може 
підвищити загальну ефективність діагностики. Методи. Мультиплексна система 3 двох ПЛР була складена для одночасної детекції криптичної плазміди i фрагмента гена 16s pРНК. Праймери на 16s рРНК можуть давати сигнал ПЛР при аналізі ряду видів Chlamydia. Додавання зонда типу Таqman (необхідного для ПЛР в реальному часі) звужує спектр виявляв видів до C. trachomatis. У той же час, ПЛР з пла-зміди володіє специфічністю виключно до C. trachomatis. Результати. Чутливість ПЛР з плазміди і гена 16s рРНК досягала від 1 до 10 геном-еквівалентів на реакцію, а ефективність - близько 100 \%. Реакція в мультиплексі не зменшує аналітичну чутливість. Додавання до реакційної суміші ДНК клінічних зразків не впливало на ПЛР з чистою ДНК C. trachomatis, що також демонструє надійність системи. Кінетику цих двох реакцій проаналізовано на 49 зразках ДНК з мазків, позитивних до C. trachomatis. Для 45 зразках показано хорошу кореляцію порогових циклів ампліфікації $C q-$ основного аналітичного параметра ПЛР у реальному часі. Висновки. Одночасна детекція хромосомної і плазмідной мішені в мультиплексній ПЛР забезпечує високу чутливість і має перевагу при аналізі зразків 3 втраченою плазмидою через деградацію ДНК або контрселекціі при терапії. Двоцільова стратегія ПЛР, може бути основою для ефективного внутрішньолабораторного або комерційного діагностичного тесту.

Ключов і слова: Chlamydia trachomatis, ПЛР у реальному часі, ген 16s pРНК, криптична плазміда

\section{Двухцелевая стратегия выявления Chlamydia trachomatis с помощью ПЦР в реальном времени}

\section{Я. А. Витренко, О. Н. Дерябин}

Мишенью тестов диагностики C. trachomatis первого поколения является криптическая плазмида. Недавно открытые штаммы без целевого сегмента ДНК(т.н. «шведские» варианты) или полностью лишенные плазмиды не диагностируются ПЦР. Цель. Предложено использовать хромосомный ген в качестве дополнительной мишени, что позволит подстраховать плазмидный ПЦР-тест и может повысить общую эффективность диагностики. Методы. Мультиплексная система из двух ПЦР была составлена для одновременной детекции криптической плазмиды и фрагмента гена $16 \mathrm{~s}$ pРНК. Праймери на 16s pРНК могут давать сигнал ПЦР при анализе ряда видов Chlamydia. Добавление зонда типа Taqman (необходимого для ПЦР в реальном времени) сужает спектр виявляемых видов до C. trachomatis. В то же время, ПЦР с плазмиды обладает специфичностью исключительно к C. trachomatis. Результаты. Чувствительность ПЦР с плазмиды и гена $16 \mathrm{~s}$ рРНК достигала от 1 до 10 геном-эквивалентов на реакцию, а эффективность - около 100 \%. Реакция в мультиплексе не уменшала аналитическую чувствительность. Добавление к реакционнной смеси ДНК из клинических образцов не влияло на ПЦР с чистой ДНК C. trachomatis, что также демонстрирует надежность системы. Кинетика этих двух реакций проанализирована на 49 образцах ДНК из мазков, позитивных по C. trachomatis. В 45 образцах реакции показали хорошую корреляцию порогових циклов амплификации $C q$ - основного аналитического параметра ПЦР в реальном времени. Выводы. Одновременная детекция хромосомной и плазмидной мишеней в мультиплексной ПЦР обеспечивает высокую чувствительность и имеет преимущество при анализе образцов с утраченой плазмидой из-за деградации ДНК или контрселекции при терапии. Двух-целевая стратегия ПЦР, может быть основой для эффективного внутрилабораторного или коммерческого диагностичного теста.

Кл юч е вы е с лов а: Chlamydia trachomatis, ПЦР у реальном времени, ген 16s рРНК, криптичская плазмида

Received 13.09.2017 